\title{
(1) http://orcid.org/0000-002-5753-376X
}

Kirsten Packham

University of New South Wales as a Masters of Fine Art Candidate

\section{HOW CAN A BODY BE ABSTRACTED?}

\begin{abstract}
The human body schema is subjugated to utilitarian modes of being and colonised by hegemonistic, culturally limited, body paradigms. Could there be strategies for redesigning the body which do not depend on technological interference? In contrast to a humanist ideal of teleological rationality and perfectibility, and to the transhumanist concern with enhancement through technology, I suggest that the site for the posthuman is the diverse body itself; and that this posthuman body is an ongoing investigation.

Abstract art allows for complexity and pluralism in the body; there is a shift from the body being the subject of the work to the body as a site of sensory experience. Similarly, experimental dance practices promote a somatosensory reorganisation, enabling access to corporeal spaces and ways of inhabiting the body which break with cultural conditioning and preconceived limits of anatomy. These two practices share a heuristic, phenomenological approach that foregrounds a perpetual transforming and kinaesthetically active body in exchange with its surroundings. The borders of the body, and the scale of our relationship to our body, shift.

I propose that a posthumanism which gives attention to the dormant minutiae of the body can give us our bodies back. Through abstraction the ontological space of the body becomes, a kinaesthetic, active site: liminal and unfolding. Instead of a trajectory of progress there is an unearthing of dormant minutiae and a perpetual, delicate dance in a constellation of relations.
\end{abstract}

Keywords: body, abstract art, sculpture, posthumanism, dance, Butoh, Body Weather, space, reflexivity

\section{Introduction}

This paper addresses how the human body schema is, on the one hand, subjugated; and on the other hand, colonized by hegemonistic and culturally limited body paradigms. The key point is that exploring approaches to the abstract body can liberate it from referentiality, function, and meaning. I propose the need for extensive enquiry and reconsideration of hierarchical attitudes to how we sense and therefore how we are embodied, which builds on ideas put forward by posthuman and metahuman thinkers such as Francesca Ferrando and Jaime del Val. In particular, as this line of inquiry sits outside the grip of technology, it corresponds to del Val's claim that our sensory 
spectrum has been reduced by perspectival technologies which seemingly renders it immobile, along with Ferrando's assertion that posthumanism should be comprehensive and "rooted in an extensive critical account of what it means to be human", asking "what does it mean to be posthuman in our existence?".

\section{The fixity of the humanistic body}

It has been argued that since the Greeks and later still in the Renaissance, that geometry was given over to a visual set of symbols and apparatus. Examples include window-based geometry, linear perspective and apparatuses such as the perspective machine devised by Leon Alberti Baptista; along with methods of standardization and the need for measurement to be universal and communicable, ${ }^{3}$ mobilising the primacy of an anthropocentric ocular-centric perspective. Jaime del Val gives an account, attributing the movement, measure and reorientation of our perceptions to be grounded in perspectival interfaces. According to del Val, these are ecologies of control that "reduce the sensory or kinetic spectrum"4 he argues that this has forged a notion of sensory immobility, reducing the multi-sensory spectrum of experience. These methods of measurement of geometry and apprehension of spatial perception gave privilege to vision; thus, a kinaesthetic, sensuous relation to the space of the body was displaced and renounced.

A dualism between mind and body pervades the hierarchical organisation of the senses. Helen Grace associates the dominance of vision in Western thought with the dominance of mind and the exclusion and denigration of the body. She argues that this line of thought is encouraged by the pervasive Kantian distrust "of bodily sensation". ${ }^{5}$ Moreover, Grace suggests that these anthropocentric, humanist ideas prevailed where "perspective located Western man at the centre of the universe and now he is slightly off-centre [...] and [...] must reorient himself". ${ }^{6}$ Perspective according to Grace, is not limited to the sphere of art, even the "sense of the absence of line presupposes an existing framework, a grid [...] in which lines, points, figures

F. Ferrando, The Posthuman: Philosophical Posthumanism and Its Others, Roma: Università di Roma Tre, 2013, p. 191.

2 F. Ferrando, "Humans Have Always Been Posthuman: A Spiritual Genealogy of Posthumanism", Critical Posthumanism and Planetary Futures 2016 (October), no. 5, p. 243.

3 J. del Val, Microsingularities: Body Intelligence, Neuroplasticecologies and Antismart Architectures in the Algoricene, 2018, pp. 65-70; M. Paterson, "The Forgetting of Touch: Geometry with Eyes and Hands", in: idem, The Senses of Touch: Haptics, Affects, and Technologies, London: Bloomsbury Publishing, 2007, pp. 59-77.

4 J. del Val, Microsingularities..., p. 65.

5 H. Grace, "Aesthesia and the Economy of the Senses", in: Aesthesia and the Economy of the Senses, ed. by H. Grace, Sydney: Faculty of Visual and Performing Arts, University of Western Sydney, 1996, p. 2.

6 Ibid., p. 5. 
might be mapped, according to a theory of vision and the representation of things". She argues that "Euclidian imaginary still inhabits us even though we know that the world is no longer flat. In the field of representation, the figure will continue to be enclosed by one or more boundaries, even though these boundaries will continually shift". ${ }^{8}$ Despite these obvious flaws, these notions were tied to sense of finiteness and gaining mastery, fitting with normative and humanist ideas of production and progress.

Philosopher, Rosi Braidotti analyses humanism as the pursuit of perfectibility, an ideal of teleologically ordained, rational progress which defines us. ${ }^{9}$ Ferrando argues that these notions of rationality, progress and optimism continue in the transhuman concern with human enhancement through science and technology. ${ }^{10}$

Performance artist Stelarc asks, "What do we do when confronted with the situation where we discover the body is obsolete? We have to start thinking of strategies for redesigning the body." es to deepening engagement with the body and embodiment. It taps into a growing argument that "the body is obsolete in the sense that it is no longer compatible with its surroundings" and in addition that "we have reached an evolutionary endpoint where the next logical stage of adaptation is for the organic to assimilate the mechanic". ${ }^{12}$

\section{A posthuman alternative to the obsolescence of the body}

Pieter Vermeulen identifies the "often excessive focus" in posthumanism on technologisation, and articulates a view that posthumanism can offer rich possibilities for thinking beyond anthropocentrism. ${ }^{13}$ Similarly, Ferrando asserts that posthumanism should be comprehensive and "rooted in an extensive critical account of what it means to be human", ${ }^{14}$ asking "what does it mean to be posthuman in our existence?"15 According to Karen Barad, "post-humanism marks the practice of accounting for the boundary-making practices by which the 'human' and its others are differentially delineated and defined". She states that posthumanism "does not presume that man is the measure of all things. It is not held captive to the distance scale of the human but

Ibid., p. 4.

Ibid., p. 5.

R. Braidotti, "Life beyond the Self”, in: eadem, The Posthuman, Oxford: Polity Press, 2013, p. 13.

10 F. Ferrando, "Posthumanism, Transhumanism, Antihumanism, Metahumanism and New Materialisms: Differences and Relations", Existenz 2013, vol. 8, no. 2, p. 27.

11 P. Atzori, K. Woolford, "Extended-Body: Interview with Stelarc", CTheory 1995.

12 R.P. O'Donnell, "Posthuman: Exploring the Obsolescence of the Corporeal Body in Contemporary Art”, Inquiries Journal/Student Pulse 2011, no. 3(8).

13 P. Vermeulen, "Posthuman Affect”, European Journal of English Studies 2014, vol. 18, no. 2, p. 124.

14 F. Ferrando, The Posthuman: Philosophical..., p. 191.

15 F. Ferrando, Humans Have Always Been Posthuman..., p. 243. 
rather is attentive to the practice by which scale is produced [...] and eschews [... the body as the natural and fixed dividing line between interiority and exteriority". ${ }^{16}$

I return to Barad's notions of agential realism and performativity in the section called Experiencing Space, which deals with indeterminate immersive spatial installation experiences and experimental dance. Essential to both of these is an expansive entanglement and porousness between the space that surrounds the body and the space of the body.

\section{How can a body be abstracted?}

My research question is: How can a body be abstracted? To answer this, I examine strategies for redesigning or moreover reconsidering the body that draw on 1) abstract art and 2) kinaesthetic spatial experience.

The strategies for reconsidering the body share a theoretical framework. The section, The Body as Space explores notions of corporeal space: how the body experiences and relates to abstract art and indeterminate perspectival space. Following this, the section Experiencing Space explores notions of dissolution of the borders of the body and entanglement with its surroundings with a heightened kinaesthetic sensitivity. These ideas are illustrated by artists and artworks, dancers and philosophers who valorise an investigatory, phenomenological methodology, and who both in theory and practice highlight an experiential and reflexive approach. Furthermore, these examples reveal how reflexivity is crucial for both performance practitioners as well as those experiencing artwork. The effect is that both areas - the subjective experience of abstract art and kinaesthetic experience - mobilise a process of attunement, emphasising dynamic felt experience, subverting readings of symbolic meaning.

The final aim is to show that it is possible to rupture rigid ideas of the body and dissolve static notions between subject and object. In Ferrando's words, posthuman philosophy "provides a suitable way of departure to think in relational and multi-layered ways, expanding the focus to the non-human realm in post-dualistic, post-hierarchical modes, thus allowing one to envision post-human futures which will radically stretch the boundaries of human imagination". ${ }^{17}$

\section{THE BODY AS SPACE}

Let's consider for a moment how we as humans in the West consider space. How do we relate to and access our interoceptive and exteroceptive corporeal space? Are the dimensions of our bodies fixed or can they shift? How does abstract art that breaks

16 K. Barad, "Agential Realism: How Material-Discursive Practices Matter”, in: eadem, Meeting the Universe Halfway: Quantum Physics and the Entanglement of Matter and Meaning, Durham: Duke University Press, 2007, p. 136.

17 F. Ferrando, Posthumanism, Transhumanism ..., pp. 26-32, p. 30. 
with perspective impact our corporeality? According to Kasimir Malevich, art has the "ability to construct $[\ldots]$ on the basis of weight, speed and movement". ${ }^{18}$

After the turn of the century, a progression in abstraction is evident in Malevich's monochrome Black Square (1915), a black square with a white border. The black form is geometrically simple and is pivotal in being a departure, not just from referentiality and anthropocentrism, but also from compositional traditions such as a vanishing point or one-point perspective. ${ }^{19}$ Yet for Malevich himself, he considered his monochrome as a "tangible expression of the infinite as it was given through non-objectivity". ${ }^{20}$ Other abstract works of the time by Malevich, such as Airplane Flying (1915) and Suprematist Painting: Airplane in Flight (1915) depict clean geometric anti-gravitational forms, freed from denotative signification of colour and released "unshackled, freshly-minted into the infinity of space". ${ }^{21}$ Malevich's works were pivotal as they "pointed to a new type of space in painting...".22 As with Black Square, Malevich frees the viewer from traditional notions of spatial orientation, such as a reference point. Inspired by aerial perspective (novel at the time), the scale of the forms in relation to each other is rendered undecipherable. There is no stable foreground, background or horizon. According to art historian John Golding, Malevich "was imagining a new, "perspective-less perspective"":

Shapes of different weights and proportions overlap and intercept, but it is impossible to gauge the distances that separate them. In his paintings there is no near, no far, no up, no down. ${ }^{23}$

The viewer has no reference point. In addition to being an expression of the infinite, Black Square has paradoxically been referred to as the zero, "a void", ${ }^{24}$ absence, the embodiment of emptiness. According to monochromatic painter Gunter Umberg, Malevich's paintings reveal an alignment of the monochrome with the body and bodily sensation. ${ }^{25}$ For Malevich, the form existed in its own right: "painting in-

18 J. Golding, Paths to the Absolute: Mondrian, Malevich, Kandinsky, Pollock, Newman, Rothko, and Still, Princeton, NJ: Princeton University Press, 2000, p. 62.

19 Psychologist of perception J.J Gibson critiques notions of perception set up and standardized since the Renaissance by Leon Alberti Battista and Filippo Brunelleschi, such as pictorial perspective, natural perspective and vanishing point as an oversimplification "as if its structure were frozen in time and as if the point of observation were motionless" (Gibson 1979, p. 70, qtd. in: R. Sullivan, "Bringing in the Body", in: idem, The Geography of the Everyday: Toward an Understanding of the Given, Athens: University of Georgia Press, 2017).

20 C. Staff, Monochrome, London: I.B. Tauris, 2015, p. 13.

21 P. Stupples, "Malevich and the Liberation of Art", Australia and New Zealand Slavists'Association 2001, p. 11.

22 M. Auping, "Four Horizons", in: M. Rothko, B. Newman, L. Fontana, Y. Klein, Declaring Space, Fort Worth, TX: Modern Art Museum of Fort Worth in association with Prestel, 2007, p. 135.

23 J. Golding, op. cit., p. 67.

24 C. Staff, op. cit., p. 13.

25 Ibid., p. 52. 
volved arousal and pure sensation in an act of creation which was bound up in bodily sensation". ${ }^{26}$

Here in the void of Malevich's Black Square and the geometric abstraction and spatial ambiguity of Airplane Flying and Suprematist Painting: Airplane in Flight, standardised measuring is abandoned enabling the sentient apparatus of the spectator to be remobilised. The anti-gravity and infinity of space in works such as Airplane Flying untether perspective. This ambiguous, destabilized and unreliable perspective is relevant to this research, as it places the viewer in an active engagement with an image. We shift from a world of standardized systems of consistent measurement and representation. Pure visual identification and a clarity of distance would undermine this. Instead the indeterminate proximities open a dialogue for spatial sensibility to emerge which is beyond a purely visual reading. This play with perspective through ambiguous proximity and unstable dimensions offers a relational aesthetic sensibility.

In the 1960s abstract painter and theorist Barnett Newman-known for his abstract colour field paintings — asserted that the innovative "capacities of abstract art [are] to initiate a larger inquiry into the human condition", that they are a "denial of dogmatic principles" and "a rejection of programmatic thought". ${ }^{27}$ Newman saw a possibility through abstraction of exploring something very real: how the mind and body process the phenomenon of space. ${ }^{28}$ British curator David Sylvester refers to Newman's thought about spatial relationships lying "outside the painting" and his approach to painting being "a model for experiencing space".

British artist Anthony Gormley is interested in subverting order and provoking reflexivity in people experiencing his work. In Quantum Void (2008-2010) ${ }^{29}$, the spectator is presented with a series of sculptures that vary in degrees of abstracting a body (Gormley's) - from those that hover on the precipice of formlessness, to the more discernible. The sculptures comprise a tenuous scattering of marks made of soldered steel, whose clustering density fluctuates depending on the angle it is viewed from. The body is suggested as airy space within a nest-like collection of rods; the spacious placement of the rods both constructs a boundary to the body and at the same time opens it so that it becomes borderless. Spectators are invited to reconsider the dimensions of the space of a borderless body. In contrast to the complete lack of representation on canvas in Black Square, or the vertically hung works of Newman, the sculptures in this series sit in space that spectators can engage from multiple angles. The small scale of the soldered rods mediates the tension between the solidity of the materiality of the steel and the expansive airy space between them

26 G. Umberg, J. Thorn-Prikker, "Black Sun: A Conversation about the Art of Painting a Black Picture", in: Gunter Umberg: Body of Painting, Cologne: Museum Ludwig, 2000, p. 94, quoted in C. Staff, op. cit., p. 52.

27 P. Kelly, "When Push Comes to Shove: Barnett Newman, Abstraction and the Politics of 1968", The Sixties: A Journal of History, Politics and Culture 2008, vol. 1, no. 1, p. 35.

28 M. Auping, op. cit., pp. 146-147.

29 M. Caiger-Smith, Antony Gormley, London: Tate Publishing, 2010, p. 97. 
which flows through the body's thresholds. Gormley does away with anatomy and traditional ways of knowing the body. The lack of inner dimensions ruptures a fixed internal body map; the boundaries of the body are open, porous.

The degrees of abstraction illustrated in Black Square and Quantum Void are broad-from complete non-referentiality in Black Square to a body reimagined with Quantum Void. However, both works invite reflexivity on behalf of the beholder with regard to the interior space of the body. ${ }^{30}$ Viewing abstract art is not passive. We see the distance between beholder and object shift in the examples of these two works. The artwork object is no longer solely beyond and separate, precious or elite. It is through sensation, the separation of artwork and spectator blurs. Object/subject dualism comes under question and a more ecological relation begins to stir. These works have correspondences with Minimal art in that they rely on the imperative of a corporeal viewer. "[T]hey confront their physical embodiment in relation to the ostensible 'object' in a spatial and temporal mode". ${ }^{31}$ The works raise questions and awareness of the agency of our soma, no longer detached from its surroundings but in a dynamic entanglement.

Like the offering of the infinite in Malevich's Black Square — an abstract body can potentially dissolve classification and tear "open the firmament" so as to "rediscover the infinite". ${ }^{32}$ The beholder of abstract art is invited to go beyond representation, narrative and literal readings. They are asked to discard their habitual expectations and modes of being. This is a liberating space for revitalised phenomenological and ontological engagement. Loosening the bonds of representation introduces a porosity in our understanding of the space of body. In Simon Sullivan's words:

Art opens us up to the non-human universe that we are part of... art also operates as a fissure in representation. And we, as spectators, as representational creatures, are involved in a dance with art, a dance in which - through careful manoeuvres - the molecular is opened up, the aesthetic is activated, and art does what is its chief modus operandi; it transforms, if only for a moment, our sense of our "selves" and our notion of the world. ${ }^{33}$

\section{EXPERIENCING SPACE}

Phenomenologist Maurice Merleau-Ponty proposed that "it is only though the body that we can truly experience space". ${ }^{34}$ Mark Paterson argues that the non-visual senses have been actively forgotten rather than casually neglected. In contrast to visual

30 R.P. O’Donnell, op. cit.

$31 \quad$ Ch. Mills, Negating Art's Ontology: Minimalism and Phenomenology, [n.d.], p. 3.

32 J. Hillier, "Liquid Spaces of Engagement: Entering the Waves with Antony Gormley and Olafur Eliasson", Deleuze Studies 2012, vol. 6, no. 1, p. 146.

33 S. O'Sullivan, "The Aesthetics of Affect-Thinking Art Beyond Representation", Angelaki Journal of the Theoretical Humanities 2001, vol. 6, no. 3, p. 128.

34 R.P. O’Donnell, op. cit. 
geometric understandings of space, Paterson claims that "our spatial experience is more than visual". ${ }^{35}$ Moreover he asserts our spatial experience is "always kinaesthet$\mathrm{ic}{ }^{36}$ and that "[p]refiguring the initial measuring process is bodily investigation and experience of space, entailing somatic movement and the use of the senses" ${ }^{37}$ Similar to the ecologies of control described by del Val, Paterson outlines that a reliance on instruments for measuring space - other than the sentient apparatus of the body itself-circumscribes to the limits of what is knowable..$^{38}$

However, once we forget the reliance on instruments for measuring space, the performativity of experience comes into question. With the body as the sentient apparatus, it becomes entangled in the space in a dynamic relationship, with shifting scale. On an agential realist account, writes Barad, "matter does not refer to a fixed substance; rather, matter is substance in its intra-active becoming - not a thing, but a doing, a congealing of agency. Matter is a stabilizing and destabilizing process of iterative intra-activity. Phenomena - the smallest material units (relational 'atoms')come to matter through this process of ongoing intra-activity". ${ }^{39}$ Barad refers to performativity as a way of contesting unexamined habits of the mind, such as language and other forms of representation that are powerful influences in determining or constraining our ontologies. ${ }^{40}$

Gormley is also concerned with probing the deep space of the body, and the body's reflexive ability to change perception of its own three-dimensional form. Through varying degrees of abstraction, he induces a defamiliarization of the body, which dislodge sedimented notions through his inquiry into both the body as space and the body's relationship to space. ${ }^{41}$ Weighty, voluminous sculptures: Still Running (19901993), ${ }^{42}$ deal with the energy of the body. Gormley brings attention to something that is somewhat indeterminate, intangible, not quantifiable. The process for this sculpture began with molds of Gormley's physical form, and then underwent a process of morphing to visibly register and capture the energy of the body while running. A weighty counter-intuitive material - cast iron - is used to capture the ephemeral energy of the body. The fluid swollen curves are top heavy, they balance gracefully as they toy with gravity. The sculpture surpasses the scale and weight of the physical body, almost comically. Perhaps this presentation and amplification of the body and

\footnotetext{
M. Paterson, The Forgetting of Touch..., p. 59.

Ibid.

Ibid., p. 61.

Ibid., p. 67.

39 K. Barad, "Posthumanist Performativity: Toward an Understanding of How Matter Comes to Matter", Signs 2003, vol. 28, no. 3, p. 822.

$40 \quad$ Ibid., p. 802.

${ }^{41}$ M.H. Hayden, “The Body: An Illusion”, From Statenskonstrad Catalogue 36, Stockholm, Sweden: The National Public Art Council, 2007; M. Caiger-Smith, op. cit., p. 95; A. Gormley, K. De Jongh, "Antony Gormley; Conversation with Karlyn De Jongh", in: P. Lodermeyer, K. De Jongh, S. Gold, Personal Structures: Time-Space-Existence, Köln: Dumont Buchverlag GmbH \& Co., 2008, p. 244.

${ }_{42}$ M. Caiger-Smith, op. cit., p. 95.
} 
the energy it exudes, is to enable the beholder to be reminded of how the supposed solid matter is composed of another, ever-present but animate matter which exceeds the confines of the utilitarian body.

Another work by Gormley, Passage (2016) ${ }^{43}$ is a vertically upright tunnel formed from the outline of the artist's body, made in weathering steel. Gormley refers to it as a 12 metre-long "journey into darkness and the unknown". ${ }^{44}$ Visitors can physically walk into the passage one at a time, entering into darkness then exiting towards light. By entering into the tunnel, the visitor commits to negotiating an intimate and solitary spatio-temporal engagement with the narrowly enclosed space. The visitor is forced into their own internal corporeality in relation to the close proximity of the tunnel walls, without the habitual reliance on the dominant sense of sight. Lois Biggs refers to the ongoing theme in Gormley's work of inner-to-outer exchange in her essay Learning to See, saying that Gormley's work "[r]eiterates the assertion that the way we make sense of the world relies on interior as much as exterior data". ${ }^{45}$ Gormley's approach to sculpture is that it's a "test ground for perception". In Blind Light (2007), ${ }^{46}$ he dissipates the dualism of interior and exterior, of borders that lead to separateness. In an expanded and less tangible relationship to space, the visitor or participant in Blind Light enters into a fog-filled room. Here too, they can no longer rely on sight. Their body dematerializes before them. Blind Light provides a space of disorientation, discovery and attunement — bodies attuning to a deeply relational and kinaesthetically heightened space. The senses are rebalanced, their usual hierarchy undermined. The importance of atmospheric work such as Blind Light, according to Peter Eckersall, Helena Grehan and Edward Scheer, "lies not so much in the fact that the atmospheres show us things or conceal things, but rather that they illuminate the production of ways of seeing that have real significance for how we live into the future". ${ }^{47}$ It is not just ways of seeing which are illuminated, but ways of sensing involving the whole body. Attention is brought to the scale of matter in Blind Light. Mist usually belongs to a larger atmosphere, but instead here in this uncustomary setting, it is contained and rescaled to rejig our apperception. Peoples relationship to sensation is altered - matter, ecology, environment, body, space merge and intermingle dissolving distinctions between subject/object.

Gormley's work shares some commonalities with Body Weather founder Min Tanaka's philosophy of movement. Tanaka's dictum that: "We live with our bodies and we perceive the world by keeping the eyes of our bodies open" 48 befits the

${ }^{43}$ White Cube Bermondsey, “Antony Gormley”, London: Fit White Cube Bermondsey, 2016.

44 Ibid.

45 L. Biggs, "Learning to See: An Introduction", London: Tate Gallery Publications, 1993.

46 A. Vidler, "Uncanny Sculpture", in: Blind Light, London: Hayward Gallery Publishing, 2007, p. 84.

47 P. Eckersall, H. Grehan, E. Scheer, "The Theatre of Atmospheres", in: iidem, New Media Dramaturgy:

Performance, Media and New-Materialism, London: Palgrave Macmillan UK, 2017, p. 102.

48 J. Marshall, "Dancing the Elemental Body: Butoh and Body Weather: Interviews with Tanaka Min and Yumi Umiumare", Performance Paradigm 2006, no. 2, p. 56. 
adaptive experience of Blind Light. Both Tanaka and Gormley seem to endorse the ecological transient ever transforming porous body-heightening awareness and connection to one's body with its surroundings. Although gravity of course remains, the participant in Blind Light has to renegotiate how to measure spatial depth. In Gormley's words, "You're awake, you're conscious, you're in space, but the space no longer has any coordinates". ${ }^{49}$ The dimensionless experience is now measured purely via the senses being called into teamwork action. It is richly multi-modal — brightness from the intense fluorescent light obstructs systems of reference, which together with moisture from the fog activates alternative modes of being. A dynamic, relational experience unfolds for the participant - a dance between dissolution and expansion into space. Peripheral, more dormant senses such as proprioception re-emerge. Speed and how one locomotes shift gears. The fog-filled room in Blind Light - and the diffused quality of the fog - could not be a more perfect metaphor for reimagining the body. Through its dematerialization the body becomes fog - thresholds of the body diffuse, soften and become sensitive to nuance as they merge with space. Light which ordinarily illuminates through predominantly ocular means, here through its blinding obstruction, elucidates via a reshuffling of the senses - allowing the body to be rediscovered. Thus, the kinetic corporeal sensitivity to one's surroundings is reflected in Min Tanaka's approach: "I do not dance in a place, I dance the place". ${ }^{50}$

The participant in Blind Light undergoes a radical hacking without the need for prosthesis. While requiring precision and technical infrastructure to regulate the atmosphere, Blind Light eloquently probes what it means to be embodied without the need for augmentation. This is a poetic alternative to customary notions of transhuman, technical cyborg intervention. The participant in Blind Light is no longer detached. Just as the participant's bodies are absorbed into space, the dualism of subject/object is expanded, so that the hard distinction between the two eases. When bodies emerge visually, they are fragmented, penumbral silhouettes, deconstructed into parts. This is an abstracted body.

\section{DANCING SPACE}

We think of the skin as defining the space between the inside and outside of the body, such that we are separated, discrete, rather than enmeshed in the world. Ongoing kinaesthetic investigations and re-imaginings of the internal to external spaces of the body are vital to both abstract art and somatic, experimental dance practices. Dance practices such as Butoh and Body Weather purge Vitruvian, ${ }^{51}$ anthropocentric ideals

49 A. Gormley, K. De Jongh, op. cit., p. 245.

50 Min Tanaka quoted by J. Kowalska, “To Be Seen”, Etnografia Polska 2005, vol. 25, no. 3, pp. 17-29, p. 17.

${ }_{51}$ M. Paterson, "How the World Touches Us': Haptic Aesthetics", in: idem, The Senses of Touch: Haptics, Affects, and Technologies, London: Bloomsbury Publishing, 2007, pp. 79-102; R. Mengham, "Visible Entropy—Antony Gormley", Ataxia 2009, no. 2; R. Braidotti, op. cit. 
of the body and approaches to movement, which are found both in the everyday social body and in codified dance practices (such as classical and contemporary dance). The body itself as a kinetic transforming material is under investigation. ${ }^{52}$ The somatic space of the body becomes anti-hierarchical, de-territorialised, plural, and in a perpetual state of transformation and exchange with its surroundings. Tanaka states "The body is not a set entity. It constantly changes, like the weather". ${ }^{53}$ Through training and techniques in Butoh, the practitioner is confronted with "a radical remapping of the dance body based on its ability to change perception of its three-dimensional form". ${ }^{54}$ Abstract art, the experience of immersive abstract artwork, and experimental dance practices position themselves outside of programmatic thought, utilitarian modes of being and technologies of perception..$^{55}$

Tatsumi Hijikata, one of the founders of Butoh dance, sought a "nonsensical vitality" and "the purposeless use of the body in a society of productivity" ${ }^{56}$ Hijikata embraced the asymmetry of his body "turning his dance in the direction of imperfection" ${ }^{57}$ - seeking to "question, deconstruct, shed or deform the body's cultural conditioning" ${ }^{58}$ Fundamental to Hijikata was the performers dancing body being resistant to static easy definition. ${ }^{59}$ In Hijikata's performance films, Stephen Barber describes Hijikata's body oscillating "between carrying a profound anatomical shock, and deliquescing into a mist of deteriorating celluloid". ${ }^{60}$ Dissolute and sybaritic in their imperfection, Butoh and Body Weather (dancers) teeter on the precipice of fragility and crisis in relentless transformation. Hijikata's valorising of the imperfect, like Newman's rejection of dogmatic principles, is an alternative to the trajectory of progress to perfection found in humanism. The antithesis to the vibrant Vitruvian body favoured in humanism, Butoh sunk its teeth into the usually discarded anatomical detritus aspects of corporeality. This customarily dismissed area was a fertile ground for investigation, using movement to explore the typically abject and reprehensible (especially in post-war Japan at the time) or marginalized bodies-illness, the aging body, a body on the precipices of death, transsexuality, gender and male homosex-

52 C. Curtin, "Recovering the Body and Expanding the Boundaries of Self in Japanese Butoh: Hijikata Tatsumi, Georges Bataille and Antonin Artaud", Contemporary Theatre 2010, vol. 20, no. 1, p. 66; S. Fraleigh, Butoh: Metamorphic Dance and Global Alchemy, Urbana: University of Illinois Press, 2010, p. 66.

53 Min Tanaka quoted in the text by J. Marshall, op. cit., p. 61.

54 R. Sweeney, "Transferring Principles: The Role of Physical Consciousness in Butoh and Its Application within Contemporary Performance Praxis", London: Middlesex University, 2009, p. 53.

55 J. del Val, Metabody Manifesto 1.0, 2013.

56 S. Fraleigh, T. Nakamura, Hijikata Tatsumi and Ohno Kazuo, New York: Routledge, 2006, p. 44.

57 Ibid., p. 47.

58 Ibid., p. 74.

59 S. Barber, "Fragments of the Human Body", in: Hijikata: Revolt of the Body, [Washington, DC]: Solar Books, 2005, p. 70.

60 Ibid., p. 65. 
uality. The Butoh performer's body is amorphous and highly available to transformation. It is not classifiable or rigid, enabling a liberated abstracted body to emerge.

A similar revolt against standard ideas of the body with foregrounding fragmentation is evident in the hybrid video and performance work Antibodies of Surveillance and Control-Microdances (2007) by del Val. In this work, the artist del Val uses cameras strapped to his naked body projecting unintelligible, images of folds and surfaces as he moves in a micro-dance, playing with an amorphous proximity, the body becoming an "excess of its parts" ${ }^{61}$ The close proximity and micro-movement disrupt traditional understandings of surveillance as something that happens at a distance. Here, a full reading of a body is made inaccessible; the body is abstracted. What is transmitted instead are the qualities of motion: folding, sonorous, breathing undulating skins. Erin Manning describes del Val's micro-dance as "not movement become form, but movement unforming [...] an excess that refuses to take form". ${ }^{62}$ The focus is on intimate and indistinguishable movement on the screen, rather than the performer in the space. Manning describes not knowing where seeing begins and the body ends - "This seeing in the feeling is a cross-modal experience - a hearing seeing, a seeing-touching". ${ }^{63}$ She gives a kinaesthetic description of becoming "participants in the web of dancer's slow mobility" and the experience of attuning to the micro-movements. Del Val's concern is with plasticity of bodies, "inducing a transformation of sensory anatomies and setting in motion an experience not of pre-established cartographies for encounter, but of immanent mappings of a body-becoming". ${ }^{64}$ Manning states that what is at stake here is a body refusing to be "a preformed entity". The performer, the depicted body and audience participate in a relational dance that elicit a sensorial, kinaesthetic state of continual emergence. Del Val's work seeks to activate modes of engagement that encourage new forces of relation to emerge. His dance seeks to create "a relational field that attunes to certain tendings in and across sensation..." ${ }^{65} \mathrm{He}$ challenges firstly the ocular-centrism expected of surveillance, and secondly the ubiquitous notion that there is a clear divide between bodies and between subject/object orientation, bridging it with a field of sensation.

${ }^{61}$ E. Manning, "Intimare", in: Intimacy Across Visceral and Digital Performance, ed. by M. Chatzichristodoulou, R. Zerihan, New York: Palgrave Macmillan, 2012, p. 129.

62 Ibid.

63 Ibid., p. 132.

64 Ibid.

65 Ibid., p. 135. 


\section{Conclusion}

Your body is actually the most highly sensitive instrument that you have in order to experience the world - Antony Gormley ${ }^{66}$

How can a body be abstracted? In this paper I have suggested various ways in which a body can be abstracted, and how this contributes to insights into what it means to be human. I have illustrated how abstraction (in both art and experimental dance) can contribute to approaches to dislodging sedimented notions of the body through a democratic reshuffling of our senses, dissolving of the borders of the body, and renegotiating the scale of our relationship to our body. This mobilises an indeterminacy that resists fixity and denies the branding of the body as finite and obsolete. It instead requires an ongoing "research attitude" that keeps us "open to innumerable mutations and unforeseeable possibilities to incalculable ways of being and knowing, doing and seeing, exposed to potentialities of which we cannot presently conceive..."67

I aimed to show how both abstract art and experimental dance practice can be posthuman without being dependent on technological intervention. Instead of a trajectory of progress and perfectibility, it is a matter of relational becoming, an unearthing of dormant minutiae, a perpetual, delicate dance in a constellation of relations.

\section{Bibliography}

Atzori P., Woolford K., "Extended-Body: Interview with Stelarc", CTheory 1995, https:// journals.uvic.ca/index.php/ctheory/article/view/14658/5526.

Auping M., "Four Horizons", in: M. Rothko, B. Newman, L. Fontana, Y. Klein, Declaring Space, Fort Worth, TX: Modern Art Museum of Fort Worth in association with Prestel, 2007, pp. 135-164.

Barad K., "Agential Realism: How Material-Discursive Practices Matter”, in: eadem, Meeting the Universe Halfway: Quantum Physics and the Entanglement of Matter and Meaning, Durham: Duke University Press, 2007, pp. 132-185.

Barad K., "Posthumanist Performativity: Toward an Understanding of How Matter Comes to Matter", Signs 2003, vol. 28, no. 3, pp. 801-831.

Barber S., "Fragments of the Human Body", in: Hijikata: Revolt of the Body, [Washington, DC]: Solar Books, 2005.

Battista S., "Introduction", in: Posthuman Spiritualities in Contemporary Performance: Politics, Ecologies and Perceptions, Cham, Switzerland: Macmillan, 2018, pp. 1-27.

${ }^{66}$ E. Yu, "Being Human: Antony Gormley's New Bodies", AFP International Text Wire in English, 2018, p. 1.

67 J. Caputo, More Radical Hermenutics: On Not Knowing Who We Are, Bloomington: Indiana University Press, 2000, as quoted in: S. Battista, "Introduction", in: Posthuman Spiritualities in Contemporary Performance: Politics, Ecologies and Perceptions, Cham, Switzerland: Macmillan, 2018, pp. 1-27. 
Bermondsey, White Cube, “Antony Gormley”, Fit White Cube Bermondsey, London, 2016, http://www.antonygormley.com/show/item-view/id/2460/type/solo.

Biggs L., "Learning to See: An Introduction", London: Tate Gallery Publications, 1993, http:// www.antonygormley.com/resources/essay-item/id/128.

Braidotti R., "Life beyond the Self", in: eadem, The Posthuman, Oxford: Polity Press, 2013.

Caiger-Smith M., Antony Gormley, London: Tate Publishing, 2010.

Curtin C., "Recovering the Body and Expanding the Boundaries of Self in Japanese Butoh: Hijikata Tatsumi, Georges Bataille and Antonin Artaud", Contemporary Theatre Review 2010, vol. 20, no. 1, pp. 56-67, https://doi.org/10.1080/10486800903453038.

Eckersall P., Grehan H., Scheer E., "The Theatre of Atmospheres", in: iidem, New Media Dramaturgy: Performance, Media and New-Materialism, London: Palgrave Macmillan UK, 2017, pp. 81-105.

Ferrando F., "Humans Have Always Been Posthuman: A Spiritual Genealogy of Posthumanism", Critical Posthumanism and Planetary Futures 2016, no. 5 (October), pp. 243-256.

Ferrando F., "Posthumanism, Transhumanism, Antihumanism, Metahumanism and New Materialisms. Differences and Relations", Existenz 2013, vol. 8, no. 2, pp. 26-32, https://doi. org/10.1075/is.11.2.01sha.

Ferrando F., The Posthuman: Philosophical Posthumanism and Its Others, Roma: Università di Roma Tre, 2013.

Fraleigh S., Butoh: Metamorphic Dance and Global Alchemy, Urbana: University of Illinois Press, 2010.

Fraleigh S., Nakamura T., Hijikata Tatsumi and Ohno Kazuo, New York: Routledge, 2006.

Golding J., Paths to the Absolute: Mondrian, Malevich, Kandinsky, Pollock, Newman, Rothko, and Still, Princeton, NJ: Princeton University Press, 2000.

Gormley A., De Jongh K., “Antony Gormley; Conversation with Karlyn De Jongh”, in: P. Lodermeyer, K. De Jongh, S. Gold, Personal Structures: Time-Space-Existence, Köln: Dumont Buchverlag GmbH \& Co., 2008, pp. 242-247.

Grace H., "Aesthesia and the Economy of the Senses", in: Aesthesia and the Economy of the Senses, ed. by H. Grace, Sydney: Faculty of Visual and Performing Arts, University of Western Sydney, 1996, pp. 1-15.

Hayden M.H., “The Body: An Illusion”, From Statenskonstrad Catalogue 36, The National Public Art Council, Stockholm, Sweden, 2007, http://www.antonygormley.com/resources/ essay-item/id/112.

Hillier J., "Liquid Spaces of Engagement: Entering the Waves with Antony Gormley and Olafur Eliasson", Deleuze Studies 2012, vol. 6, no. 1, pp. 132-148, https://doi.org/10.3366/ dls.2012.0051.

Kelly P., "When Push Comes to Shove: Barnett Newman, Abstraction and the Politics of 1968", The Sixties: A Journal of History, Politics and Culture 2008, vol. 1, no. 1, pp. 27-47.

Kowalska J., “To Be Seen”, Etnografia Polska 2005, vol. 25, no. 3, pp. 17-29, https://doi. org/10.1520/F2900.

Manning E., "Intimare", in: Intimacy Across Visceral and Digital Performance, ed. by M. Chatzichristodoulou, R. Zerihan, New York: Palgrave Macmillan UK, 2012.

Marshall J., "Dancing the Elemental Body: Butoh and Body Weather: Interviews with Tanaka Min and Yumi Umiumare", Performance Paradigm 2006, no. 2, pp. 54-73.

Mengham R., "Visible Entropy-Antony Gormley", Ataxia 2009, no. 2, http://www.antonygormley.com/resources/essay-item/id/120. 
Mills Ch., "Negating Art’s Ontology: Minimalism and Phenomenology", Goldsmiths College, University of London, https://www.academia.edu/17429793/Negating_Arts_Ontology_ Minimalism_and_Phenomenology [n.d.].

O’Donnell R.P., "Posthuman: Exploring the Obsolescence of the Corporeal Body in Contemporary Art", Inquiries Journal/Student Pulse 2011, no. 3(8).

O'Sullivan S., "The Aesthetics of Affect-Thinking Art Beyond Representation", Angelaki Journal of the Theoretical Humanities 2011, vol. 6, no. 3, pp. 125-135, https://doi. org/10.1080/0969725012008798.

Paterson M., “How the World Touches Us': Haptic Aesthetics”, in: idem, The Senses of Touch: Haptics, Affects, and Technologies, London: Bloomsbury Publishing, 2007, pp. 79-102.

Paterson M., "The Forgetting of Touch: Geometry with Eyes and Hands", in: idem, The Senses of Touch: Haptics, Affects, and Technologies, London: Bloomsbury Publishing, 2007, pp. 59-77.

Staff C., Monochrome, London: I.B. Tauris, 2015.

Stupples P., "Malevich and the Liberation of Art", Australia and New Zealand Slavists' Association 2001, pp. 11-36.

Sullivan R., "Bringing in the Body", in: idem, The Geography of the Everyday: Toward an Understanding of the Given, Athens: University of Georgia Press, 2017.

Sweeney R., "Transferring Principles : The Role of Physical Consciousness in Butoh and Its Application within Contemporary Performance Praxis", London: Middlesex University, 2009.

Umberg G., Thorn-Prikker J., "Black Sun: A Conversation about the Art of Painting a Black Picture", in: Gunter Umberg: Body of Painting, Cologne: Museum Ludwig, 2000.

Val J. del, Metabody Manifesto 1.0, 2013, http://metabody.eu/metabody-manifesto-1-0-2/.

Val J. del, Microsingularities: Body Intelligence, Neuroplasticecologies and Antismart Architectures in the Algoricene, 2018, pp. 65-70.

Vermeulen P., "Posthuman Affect", European Journal of English Studies 2014, vol. 18, no. 2, pp. 121-134, https://doi.org/10.1080/13825577.2014.917001.

Vidler A., "Uncanny Sculpture", in: Blind Light, London: Hayward Gallery Publishing, 2007.

Yu E., "Being Human: Antony Gormley's New Bodies", AFP International Text Wire in English, 2018. 